\title{
FORUM
}

Submitted 05.05.2013. Approved 01.17.2014

Evaluated by double blind review. Scientific Editors: Wesley Mendes-Da-Silva, Newton C. A. da Costa Jr, Lucas Ayres,

Manuel Rocha Armada and Jill M. Norvilitis

DOI: http://dx.doi.org/10.1590/So034-759020150106

\section{ANTECEDENTS AND CONSEQUENCES OF HOUSEHOLD FINANCIAL MANAGEMENT IN BRAZILIAN LOWER-MIDDLE-CLASS}

\author{
Antecedentes e consequências do gerenciamento das finanças domésticas na classe \\ média baixa brasileira
}

\section{Antecedencias y consecuencias de la administración financiera doméstica en la clase media baja brasileña}

\begin{abstract}
Through two complementary and exploratory studies - one qualitative and one quantitative - this research aims to understand the ways in which lower-middle-class families in Brazil manage their household finances. The study proposes an integrated framework that brings together various previously disconnected theoretical fragments. Based on a survey with a sample of 165 lower-middle-class female consumers of a retail company in São Paulo, we explored and tested, via a quantitative study, how antecedents such as personal characteristics affect the financial management process, as well as its consequences, either negatively as defaults or positively as savings. The model calibration and analysis were derived from a series of regression analyses. The results revealed the mediator role that financial management plays in the relationship between personal characteristics and defaults and savings. Compared to previous studies with consumers of more affluent countries, we identified peculiar findings among Brazilian lower-middle-class consumers: inadequate attention to control, weak or no focus on short- or long-range planning, widespread absence of budget surplus, and influence of critical events on episodes of default.
\end{abstract}

KEYWORDS | Household financial management, mental budget, default, savings, Brazilian lower-middle-class.

\section{RESUMO}

Por meio de dois estudos exploratórios complementares - um qualitativo e outro quantitativo - esta pesquisa objetivou compreender como as famílias de classe média no Brasil fazem sua gestão financeira. O estudo propõe uma estrutura integrada reunindo vários fragmentos teóricos anteriormente desconectados. Baseado em um levantamento em uma amostra de 165 consumidoras de classe média baixa de uma empresa varejista em São Paulo, exploramos e testamos como antecedentes, como características pessoais, afetam o processo de gestão financeira; e como esse processo gera consequências negativas como inadimplência, ou positivas como poupança. O modelo foi testado por meio de uma série de análises de regressão. Resultados revelam o papel mediador da gestão financeira na relação entre características pessoais e as respostas de inadimplência ou poupança. Comparado aos consumidores de países ricos, identificamos comportamentos peculiares dos consumidores da classe C no Brasil: foco inadequado no controle, pouca ou inexistente atenção no planejamento de curto e médio prazo, ausência generalizada de poupança, e influência de eventos críticos em episódios de inadimplência.

PALAVRAS-CHAVE / Gestão das finanças domésticas, orçamento mental, inadimplência, poupança, classe média baixa brasileira.

\section{RESUMEN}

Mediante dos estudios exploratorios complementarios - uno cualitativo y otro cuantitativo-, la presente investigación tiene como objetivo entender los medios por los cuales las familias de clase media-baja brasileña administran sus finanzas domésticas. El estudio propone un marco integrado que reúne varios fragmentos teóricos previamente no relacionados. Basándonos en una encuesta realizada con una muestra de 165 consumidoras de clase media baja, de una empresa minorista en São Paulo, exploramos y examinamos, mediante un estudio cuantitativo, qué antecedentes, tales como características personales, afectan el proceso de administración financiera, así como también sus consecuencias, ya sea negativamente como incumplimientos de pago, ya sea positivamente como ahorros. La calibración y análisis del modelo derivaron de una serie de análisis de regresión. Los resultados revelaron el papel mediador que la administración financiera cumple en la relación entre las características personales y el impago y los ahorros. En comparación con estudios previos sobre consumidores de países más ricos, llegamos a conclusiones peculiares con respecto a los consumidores de la clase media-baja brasileña: insuficiente atención al control, poca o ninguna importancia otorgada a la planificación a corto o largo plazo, ausencia generalizada de superávit presupuestario, e influencia de eventos críticos en los eventos de impago.

PALABRAS CLAVE I Administración financiera doméstica, presupuesto planificado, impagos, ahorros, clase media-baja brasileña. 


\section{INTRODUCTION}

Nearly all consumers' spending comes from the same set of limited resources: individual or family income. Spending in different categories can compete for winning a share of the household budget (Du \& Kamakura, 2008). Research on consumer behavior with respect to the way households manage their finances and make their choices provides a greater understanding of this important phenomenon, as it reveals how consumers allocate their resources, track their expenses and manage their budgets. From a business point of view, an understanding of household financial management processes can help companies make better decisions about granting credit to consumers, and thus minimize the occurrence of default. From a public-policy perspective, a deeper understanding of the personal finance process can help the public sector develop educational strategies to help families, especially those in less affluent segments, to better plan and manage their budgets, to allow savings and avoid defaults.

The question of how families manage their finances has been investigated within an emerging area of knowledge called financial decision-making. This area mainly comprises studies on expenditure patterns and resource allocation, loans and payment (or nonpayment), savings, and purchases of complex financial products (Lynch, 2011; Du \& Kamakura, 2008; Kirchler, Hoelzl, \& Kamleitner, 2008; Soman \& Cheema, 2011; Antonides, Groot, \& Raaij, 2011; Amar, Ariely, Ayal, Cryder, Rick, 2011). Just recently, understanding of how domestic financial decisions are made has become a main focus of studies in marketing (Lynch, 2011).

The management of household finances involves controlling and tracking expenditures and revenues. In this study, we considered the household finance management construct as being comprised of the following two components: financial control (Antonides, Groot, \& Raaij, 2011), mental budgeting (Heath \& Soll, 1996; Thaler \& Sustein, 2009; Antonides, Groot, \& Raaij, 2011). Financial control refers to how consumers manage their revenues and expenses. Mental budget helps consumers with household budget planning and control, and refers to how people mentally divide and group resources and expenditures in various categories (Heath \& Soll, 1996; Thaler \& Sustein, 2009). Although these are closely related activities, previous studies have not explicitly related household finances management with the practice of creating a mental budget.

In Brazil, the increase in credit offers, the consumers' little finance knowledge, and high interest rates (despite efforts to reduce them), form a risky equation that ends up stimulating situations of consumer default. The delinquency rate of Brazilian consumers in 2012 reached $7.9 \%$, according to data from the
Banco Central (2013). Although the situation is under control according to the government, the situation is not so straightforward for families with these problems.

In recent years, most studies on debt have shown great concern about the rising default rates in the US housing sector, as well as increases in debt on credit cards. Most of these studies have dealt with macroeconomic aspects, developed models for predicting default, and investigated the strategies adopted by consumers to manage and prioritize which bills to pay and which they will have a default condition (for example: stop paying house mortgage to continue getting credit for some other essential expenses) (Mayer, Pence, \& Sherlund, 2008; Anderson, Chomsisengphet, \& Glennon, 2011).

This study contributes to the knowledge in the field, gathering, in an integrated framework (Figure 1), various previously disconnected theoretical fragments to offer a better understanding of the financial management process and its consequences - savings and defaults. Our analysis adopted a framework usually found in consumer behavior models in which consumer responses are influenced by two major set of variables: personal characteristics and sociodemographic variables, such as age, lifecycle, and education level. Based on literature review, three personal characteristics became more evident when analyzing the influence on the household financial management behavior: self-control (Tangney, Baumeister, \& Boone, 2004; Baumeister, 2002), preference for the use of credit (Prelec \& Lowenstein, 1998; Ponchio, 2006), propensity to plan (Lynch, Netemeyer, Spiller \& Zammit, 2010). The constructs of financial control (Antonides, Groot, \& Raaij, 2011) and mental budgeting (Heath \& Soll, 1996; Thaler \& Sustein, 2009; Antonides, Groot, $\&$ Raaij, 2011) are the consumer responses which comprise the household finance management behavior.

Issues related to the management of household finances have usually been studied in the context of developed countries, especially the US and Europe, and, therefore, reflect the behavior of more affluent consumers who, in general, already have their basic needs comfortably satisfied, thanks to less restricted budgets. Although the budget management phenomena can be observed at all income levels, the empirical research with consumers from Brazilian low-middle-class families may present peculiar characteristics due to a number of factors related to a much more restricted income and lower levels of education; these factors include most income committed to the essential aspects of survival; a lack of financial reserves; fluctuations in the level of income due to informal work; insufficient education to allow a more detailed monthly financial planning; and a lack of propensity and mathematical skills to think about and plan for future time horizons. 
In this study, we seek to extend the knowledge in financial decision-making by investigating the antecedents and consequences of managing household finances among consumers within low-middle-class families in Brazil. More specifically, the study aims to: (1) investigate and test the influence of personal characteristics (self-control, preference for the use of credit, and propensity to plan) and sociodemographic variables (age, level of formal education, and stage in the lifecycle) for each component of household financial management - financial management itself, and mental budget; (2) investigate how each of these two components influences the occurrence of default and savings; and (3) investigate whether the management of household finances is a mediating variable that helps explain the relationship between personal characteristics and the occurrence of default and savings.

The remainder of this paper is organized in five parts. The literature review offers a structured conceptual overview of the variables and relationships included in our proposed model, while the methodology briefly describes the investigation procedures selected for the qualitative and quantitative methods. The findings are presented separately in two parts: one with the qualitative investigation results and one with the quantitative research findings. Lastly, the paper integrates the findings from both methodological approaches, and presents conceptual and managerial implications, research limitations, and suggestions for further studies.

\section{LITERATURE REVIEW}

\section{Household financial management}

Lynch (2011) argues that the household financial management field of study has no well-defined boundaries; although it is possible to consider any purchase as a financial decision, the author argues that financial decisions are those that have the potential to change the consumer's financial situation due to just one expense, or the cumulative effect of repeated behavior patterns derived from personal characteristics, skills and habits. The choice of financial products (e.g. insurance, loans, investments, etc.) to improve consumers' financial situations can also be considered financial decision-making (Lynch et al. 2010, Soll, Keeney, \& Larrick, 2011; Spiller, 2011; Thaler \& Benartzi, 2004). For consumers with limited income, such as low-middle-class Brazilians, even a consumption decision considered trivial to more affluent consumers can have a strong impact on household finances. Thus, in this context, a greater number of decisions can be considered as financial decisions. We consid- er mental budget and financial control as the two components of the household finance management construct.

\section{Mental budget}

The mental budget concept is derived from studies on mental accounting developed by Thaler (1985). Mental accounting is defined as "the system (sometimes implicit) that families use to evaluate, regulate and manage their household budget” (Thaler \& Sustein, 2009, p. 53). Thaler (1993) states that mental accounting helps make better predictions about the consumer behavior, which differ from those in conventional economics or psychology (Webley, 1995).

Heath and Soll (1996) propose a mental budget model that focuses on the question of how resources are grouped and named. In this model, consumers set budgets for various expenses, such as home shopping, clothes or food. The expenses are in turn allocated to these corresponding accounts, and deducted from the balance. For Heath and Soll (1996), this type of budget and expenditure allocation has a great impact on purchasing decisions in each category. Previous studies recognize that mental budget influences the purchasing decisions of consumers, and increases individuals' awareness about their financial situation, since it makes this information more salient in their minds, thus contributing to greater control over expenses and therefore less chance of indebtedness.

\section{Financial control}

In order to control finances in the family environment, consumers must manage their income and expenses. This management can result in a negative balance, meaning that consumers face difficulties in paying their bills, or a positive balance, which enables them to save for future needs.

Studies on family budget have been conducted since early 2oth century, due to the efforts of the Bureau of Labor Statistics to map the pattern of consumption within US households (Johnson, Rogers, \& Tan, 2001). These studies are more extensive and frequent in the field of microeconomics than in marketing, where few advances have been seen recently. In economics, the main issue has been the trade-offs that consumers make when choosing between immediate consumption and future consumption (Du \& Kamakura, 2008). Even considering its importance, there are few empirical studies that relate marketing to family budgeting (Du \& Kamakura, 2008). In Brazil, exceptions to this are the studies of Silva (2004) and Silva, Parente and Kato (2009). In general, marketing studies bring few discussions about the composition of household budgets, how they are determined, and how families manage them. 
Individuals that apply a better management of their revenues and expenses tend to avoid situations in which their expenditures exceed their earnings, thus reducing their risk of default. Recurrent thoughts about their expenses tend to stimulate control, since they have more opportunities to reconsider and control their purchasing decisions.

\section{Antecedents of household financial management}

Consumers' personal characteristics, such as self-control, preference for credit, and propensity to plan, have the potential to influence their financial decision-making.

\section{Self-control}

Self-control can be understood as a person's ability to replace or change their internal responses, stop unwanted behavior tendencies (such as impulses), and thereby avoid behaviors arising from these tendencies (Tangney, Baumeister, \& Boone, 2004). It can also be understood as an individual's ability to change and adapt to enable their best fit in the world (Rothbaum, Weisz, and Snyder, 1982). From this perspective, self-control should generate a number of positive outcomes for individuals, including the control of impulses, such as the impulse to shop. High levels of self-control are related to better management of finances, leading individuals to save more and spend less, and have the long-term focus (Tangney, Baumeister, \& Boone, 2004; Baumeister, 2002).

\section{Preference for credit}

Several studies in the field of Behavioral Economics have investigated the impact of different forms of payment during consumption. When individuals shop, they experience what is called the "pain of paying" (Prelec \& Lowenstein, 1998). This negative feeling can decrease the satisfaction resulting from consumption. This kind of pain derived from making payment has an important role in the self-regulation of consumption. Payment by credit card or other financing can weaken the relationship between payment and consumption, thereby minimizing the negative influence that the payment has on satisfaction. Consequently, individuals that use some sort of credit for payment may consume more. The question arises as to whether this will lead to greater consumption, which in turn causes them to become delinquent (Prelec \& Lowenstein, 1998; Soman \& Lam, 2002; Soman \& Cheema, 2002; Kirchler et al., 2008; Raghubir \& Srivastava, 2008; Ponchio, 2006).

\section{Propensity to plan}

Planning has important effects on consumer behavior and the choices made over time. Propensity to plan and its effects vary with the situation and from person to person. Propensity to plan may be understood as a reflection of individual differences in terms of (a) frequency in designing goals, (b) frequency and depth in the definition of sub-goals, (c) use of reminders to help see the big picture and restrictions, and (d) personal preference to plan (Lynch et al., 2010). It can be assumed that consumers that tend to plan their finances for the long run can manage their household finances better, since they anticipate costs and expenses in relation to their budget, which improves their ability to make predictions. There are, however, insufficient studies correlating the propensity to plan and the occurrence of default and saving (Lynch et al., 2010; Katona, 1974; Soman 1998).

\section{Consequences of household financial management}

Default can be understood as the failure to fulfill the obligations of an agreement or its conditions. One possible explanation for this behavior is that the individual has difficulties in exercising self-control. According to Webley and Nyhus (1998), this behavior is as a result of the temptations experienced, and the ability to exercise self-control in situations where there is conflict between short-term (spend now) and long-term (solid household budget) goals. When consumers see a new consumption opportunity (promotion of favorable installments and payment terms), they tend to overestimate this opportunity and underestimate the impact of their decision to spend on their long-term planning (e.g. savings).

Saving involves avoiding consumption for a certain period in favor of possible future consumption. From a psychological point of view, it is related to how people deal with uncertainty and how they make provisions for the future to ensure that they will have resources for consumption (Wärneryd, 1989). Saving can also be understood as a complementary activity to the consumption function, and is derived from two sets of factors: ability to save and willingness to save. Ability is a function of income, while willingness is a subjective measure that considers the level of optimism or pessimism of the population (Katona, 1974). Wärneryd (1989) presents different models of savings developed over the years by economists and psychologists to understand the saving behavior of consumers. Based on personal characteristics and demographic variables, models have been built over time, aiming to improve the understanding of the behavior towards saving. 


\section{Contributions from Brazilian researchers}

In Brazil, there has been a significant growth in academic research about the interface between psychology and economics, with emphasis on behavioral finance (Ferreira, 2007). The behavioral finance research has been developed in Brazil with a main focus on explaining the behavior of financial agents (Halfeld \& Torres, 2001; Kimura, Basso, \& Krauter, 2006; Oliveira, Silva, \& Silva), and, more recently, the influence of this behavior on decision processes (Fonseca \& Muramatsu, 2008; da Silva, Lagioia, Maciel \& Rodrigues, 2009; Cappellozza \& Sanchez, 2011). Ferreira (2007) suggests that studies in economic psychology in Brazil should address the major issues faced by Brazilian consumers and offer contributions to guide the development of more adequate public policies. However, from the point of view of Behavioral Economics, we were unable to find studies in Brazil directly related to our research area - i.e. understanding how families make their financial decisions, and the impact of those decisions on their financial situation.

\section{Proposed framework}

Based on the qualitative research findings and on the literature review, the framework illustrated in Figure 1 gathers, in an integrated conceptual model, various previously disconnected theoretical fragments related to the household finance management phenomenon. The model identifies the antecedents and consequences of the household financial management construct, which is, as previously explained, comprised of two components: financial control and mental budget. Three personal characteristics (self-control, preference for credit, and propensity to plan) and three socio-economic variables (age, lifecycle, and education (evel) are included as antecedents in the model. The occurrence of unexpected critical events (such as sickness and accidents) is also included as an antecedent of the financial management process. This variable emerged from the preliminary qualitative research as a relevant determinant of the interviewees' financial problems. Defaults and savings are considered major outcomes of the financial management process. These two alternatives are not necessarily mutually exclusive, as we did find a relevant number of families that simultaneously had savings and defaults. The components of household financial management appear to mediate the relationship between the antecedents and the occurrence of default and savings. While the findings from the qualitative stage of the research helped design the proposed model, the quantitative stage tested the relationships among the model variables.

Figure 1. Conceptual Framework

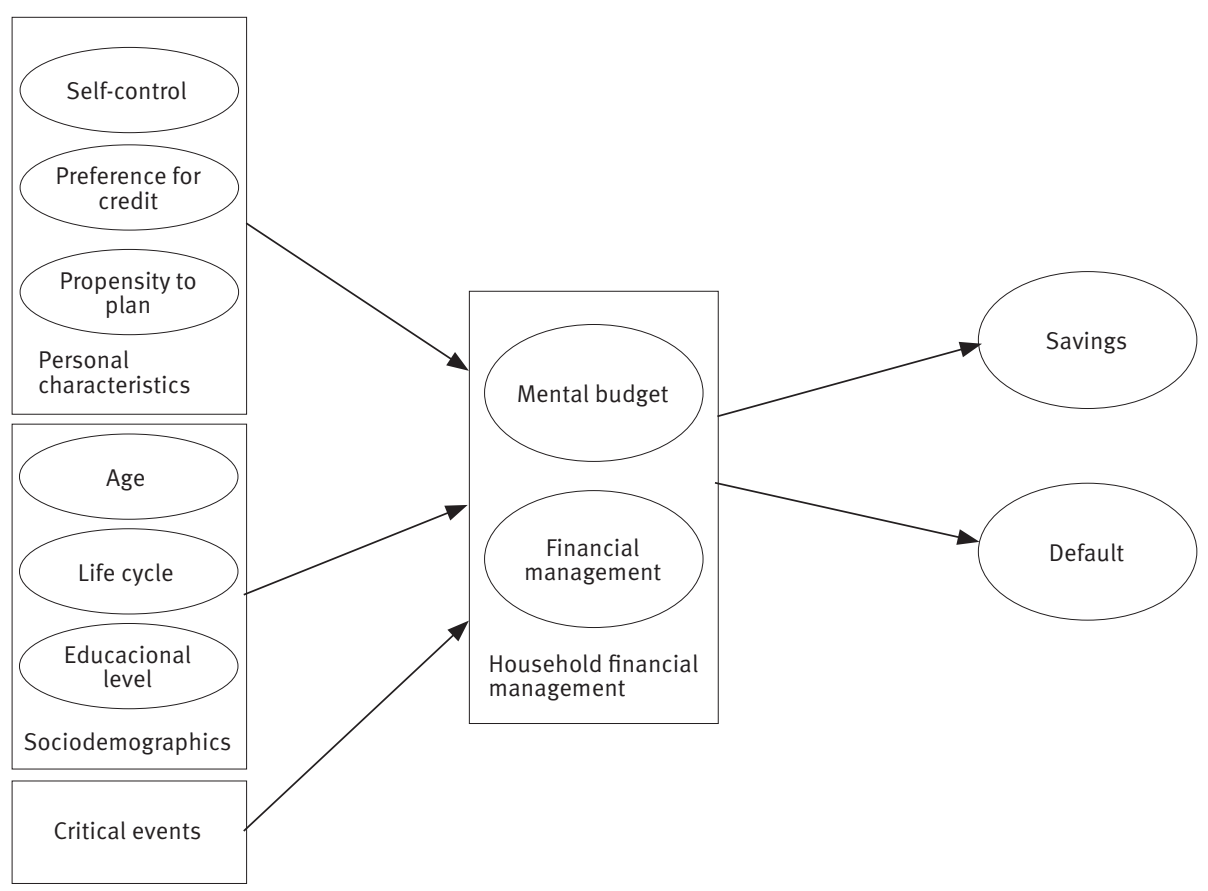




\section{METHODOLOGY}

This research was conducted via two complementary studies: one qualitative and one other quantitative. The qualitative stage was exploratory and provided a greater understanding of the phenomenon and the initial structuring of the proposed model. The quantitative stage enabled testing of the relationships proposed in the model.

In both stages we chose to include only females. Women are usually responsible for the control of finances, even when purchasing decisions are mostly made by men, and women are often responsible for the control of payments (Kirchler, Hoelzl \& Kamleitner, 2008). In this study, our sample of consumers was extracted from the Brazilian lower-middle class - i.e. families with a monthly income between $R \$ 1,200.00$ and $R \$ 5,174.00$ (approximate exchange rate: $\mathrm{R} \$ 2.00=$ US\$1.00) (Neri, 2011). Comprised of 100.5 million consumers, this segment represents about $50 \%$ of the country's population. Credit cards in this segment are widely used. About $76 \%$ of Brazilians have some means of electronic payment, and $23 \%$ of the population that don't have their own card often borrow it from a friend or family (ABECS, 2013).

\section{Qualitative study}

In the qualitative stage, data were collected through in-depth interviews using an open-ended semi-structured questionnaire. The sample was obtained through the authors' network of relationships and recommendations from the interviewees themselves. To define the number of interviews we followed the principle of saturation, in which the interviewing stage is considered sufficient when new interviews begin to bring the same information as that previously collected. In total, 22 women were interviewed. The data analysis was based on a template technique.

\section{Quantitative study}

The quantitative stage utilized a relational research approach. The sample was obtained from the consumer database of a leading Brazilian apparel retailer, and included 3000 names of customers who had the store's credit card. These consumers were selected according to the following criteria: age (between 30 and 60 years), place of residence (city of São Paulo), and belonging to lower-middle class. These consumers were divided into two groups, $A$ and $B$, according to the retailer records of their different default conditions: Group A - not in default; and Group B - in default. The adopted procedure ensured that the financial situation of the consumers that participated in the survey remained confidential. We contacted 2,057 consumers, and 165 valid responses were obtained. The results of the empirical analysis should be interpreted with caution and should not be fully generalized to the entire population of Brazilian lower-middle-class households, as the sample was restricted to women living in Sao Paulo and customers from a specific retailer.

The independent variables that reflect the respondents' personal characteristics (self-control, preference for credit, and propensity to plan) and the constructs that reflect consumer behavior in relation to managing their finances (financial control and mental budget) were assessed through scales that had already been developed, tested and validated in prior research. For questions regarding the latent constructs (self-control, preference for credit, and propensity to plan) we used a five-point Likert scale extracted from existing literature. The self-control construct had 12 indicators (scale adapted from Tangney et al. (2004)), preference for credit had three indicators (scale adapted from Ponchio (2006)) and propensity to plan had six indicators (scale adapted from Lynch et al. (2010)). Except for the scale for preference for credit, which had been developed in Portuguese, all the other scales had been developed in English. The questions were translated (from English to Portuguese), validated and pre-tested using ten consumers who had the same profile as the sample, which allowed adjustments to the questionnaire as needed. Data were collected between October 14 and November 26,2012 , in the form of telephone interviews, by a specialized researcher.

\section{RESULTS OF QUALITATIVE STUDY}

The qualitative study revealed a wide variety of consumer behaviors, and showed that different levels of control influence the purchasing behavior of households, and affect their ability to pay and/or save. This study provided a valuable understanding of how consumers evaluate, regulate and process their household budgets, and revealed some of the strategies used to promote their self-control and, consequently, avoid any risk of default. A total of 22 women aged between 22 and 65 were interviewed. Among the respondents there were housewives, nannies, hairdressers, maids, secretaries, students and sales representatives. Several major categories or codes emerged from the data analysis. In order to facilitate our understanding, these codes were reorganized and presented according to the conceptual framework previously presented. 


\section{Financial control}

A large proportion of the respondents reported that they control their family's expenses in some way. Different levels of control were noted: some of the respondents stated that they systematically record their household expenditures - paid either by cash or credit card - in paper notebooks. Others demonstrated a fairly accurate understanding of their expenses, although stating that they are not in the habit of making notes. Their control was found not only in regular levels of monthly expenses, but also in exercising discipline in spending their money.

When I get home I write down the expenses to see if I can spend more, and when [I] reach it (the salary limit), I stop. (...) for me the most important thing is not to transfer any debt to the next month. (Consumer A, 40).

We have a joint account, we hardly use the credit card, even (...) food, we pay with money (...) we always spend the same amount (...) he (the husband) doesn't take any notes, but he handles it well. (Consumer E, 53).

Some of the interviewees revealed difficulty in taking precise control of expenses, and stated that they use their credit limit as a tool to control their spending. They recognized that exceeding this limit control causes them problems with respect to paying their debts.

Actually I don't usually write down the expenses. When I buy something I add the amounts together. If I could have a better control, I think I wouldn't have so much trouble to pay for everything (Consumer R, 50).

This month I exceeded the limit of my credit card, I don't know what to do. (Consumer U, 39).

Considering the practice of mental budgeting, the research revealed that mental accounts are kept by most interviewees, as foreseen by the mental accounting theory (Heath \& Soll, 1996). These accounts are usually identified in terms of priorities: basic accounts (electricity, water, telephone) and credit cards - which entail several mental accounts: food, clothing, leisure, medicine, etc. The credit card seems to work as a great simplifier in mental accounting, as it allows to group several accounts into one single account. According to Heath and Soll
(1996), people impose limits to their mental accounts, and this was confirmed by our interviewees.

Interviewees with an unstable and variable household income showed a need for tighter control of their finances to fulfill their commitments. Some of these women showed greater difficulties in exercising planning and control.

I have to be more careful and save money during the months our revenues drop. In January and July, my income drops a lot, so two months before I begin to keep all $R \$ 1.00$ (coins) in a safe deposit and during my lower-income month I use these savings to pay the bills (Consumer L, 37).

\section{Household financial management antecedents}

Self-control, as a personal characteristic or personality trait, also appears to influence the behavior of consumers in relation to controlling their finances, as foreseen by Tangney et al. (2004).

I've always been (in control), since I was younger. I don't buy much, only what I need (Consumer E, 52).

Many of the interviewees stated that they have credit cards, which was the primary financing instrument for these families. The interviewees' reports confirm the findings of Prelec and Lowenstein (1998) in terms of decreasing the negative result of the pain of payment when using a credit card. Postponing the payment for the next month seems to increase consumers' satisfaction with the purchase.

Now I buy everything, even food (using a credit card). I never use money, I buy everything with the credit card, but I control everything. It is much easier to use and I don't need to have money to pay for things (Consumer A, 40).

A small portion of the interviewees, however, avoid credit cards because of their aversion to debt. Their relationship with credit cards and the financial system as a whole is generally mistrustful. While recognizing the benefits of using credit cards, they revealed a fear of using them.

I pay in cash, or when something is too expensive, I borrow a credit card. I don't have one because I don't really understand how it works. The bank always offers me one, but I don't want it yet (Consumer D, 21). 
Sharing a credit card with a sister or friend was a frequent theme among the interviewees. In some cases, the strategy behind this is to avoid the cost of credit card fees. In other situations, using another person's credit card contributes to self-control at the time of purchase.

I do not have my own credit card. I use a card that belongs to a friend of mine (...) because, if I use my credit card, I end up spending too much, so I borrow the card from her and I know I'll spend wisely. (Consumer P, 35).

A surprising aspect emerged from this research: although many consumers revealed that they control their expenses, few of them showed any concerns in relation to planning their budget. There seems to be a greater dedication to controlling expenses, rather than planning before spending. This shows the difficulty these consumers have in predicting expenses before they occur. As a result of this planning difficulty, a large proportion of the interviewees considered that it was impossible for them to save money, even though they recognized the discount they could obtain in avoiding the use of credit.

I do not plan when I buy things. I only control after I buy it, so I know when to stop spending (Consumer J, 27).

The different stages of lifecycle influence the way the respondents control their expenses. Motherhood often appears to be a turning point in dealing with money. As Neri (2011) argues, motherhood makes women give more forethought to their finances. Some respondents said that motherhood made them behave totally differently compared to before they became mothers, when they were less concerned about money, spent more irresponsibly, and exercised less control.

I've been exercising this control over expenditures since my daughter was born, because before I had no control; my relatives, my cousins always said that I had no control of anything, but after my daughter was born I developed more control, for the sake of her, right? (Consumer B, 35).

\section{Household financial management consequences}

Some interviewees experienced periods of default because they spent more than they were able to pay. The negative experience of these situations seemed to make them more aware of the risks of default. Delinquencies were often justified by the occurrence of events in which the consumer had no control, such as unemployment, divorce, etc.

When I was in default (...) it was during a hard time for me. I had just got divorced, and I was having troubles (...) it was difficult to pay the debts (Consumer R, 50).

Studies regarding lower-income Brazilian consumers demonstrate that they face difficulty in saving money, whether for retirement, to purchase some higher-value good, or for emergencies (Mattoso, 2005). Our respondents envisaged savings as a desirable objective, but hard to achieve. They indicated that their income is often not enough to offset their consumption. Since most do not have savings, a large part of this group said that they turn to family for help whenever they are in need. Only a minority of them choose to borrow from banks.

In case of an emergency I would ask my family for money, I think it is natural, my mother would help me or my cousins (Consumer J, 27).

The results obtained from this qualitative stage of the study helped improve the understanding of the household financial management process, and also showed new variables not presented in prior research in this area. The importance of the lifecycle in direct relation to financial management was one aspect that emerged from this qualitative analysis that was not found in the literature review. Other findings also emerged from this stage, such as a relationship between certain events (unemployment, divorce, etc.) and default. The different forms of control, poor or non-existent planning, the strategies used by the respondents to promote self-control, as the use of credit cards were findings incorporated into the quantitative modeling stage of the study.

\section{RESULTS OF THE QUANTITATIVE STUDY}

Descriptive analyses were performed to evaluate the data adequacy for further examination. The scales were tested using a confirmatory factor analysis (CFA), in which we tested the convergent and divergent validity of the constructs, and the reliability of the measurements. The analysis of the relationships between the variables was conducted via linear and binary logistic regressions. 


\section{Sample characteristics}

Of the 3000 consumers from the two databases, 2057 were contacted (793 in Group A, and 1264 in Group B), but we obtained only 194 completed questionnaires. Among the respondents, 28 declared a household income above $\mathrm{R} \$ 5,174.00$, which placed them outside the income range corresponding to the lower-middle class, and one consumer was aged under 30 . These responses were eliminated, leaving 165 to be considered for the analysis.

The situation of default for each respondent was determined from their presence in one of the groups in the database. We expected to obtain samples of the same size, but, due to high dropout rate during the interviews, it was much more difficult to complete interviews with the consumers in the default sample. The distribution of the total sample of respondents was $58.8 \%$ non-default and $41.2 \%$ default. It should be noted that this proportion is not representative of all retail clients - the average default index of Brazilian consumers was 7.9\% in 2012 (Banco Central, 2013).

Most respondents (66.1\%) did not have any savings or cash reserves. This result confirms the qualitative stage findings, in which only a minority had some form of resource reserve. When asked about the purpose or intent behind saving, setting aside money for emergencies appeared to be the main purpose for most consumers ( $72.1 \%$ of respondents). Saving money to buy something of value appeared in $17.6 \%$ cases, while only $10.3 \%$ of respondents stated that the purpose of the cash reserve was retirement. This result also confirms the qualitative research findings, which reflect less concern about retirement and a greater concern about emergency situations, indicating that these consumers experience a greater sense of vulnerability regarding their finances.

The age of the 165 respondents was between 30 and 60 , with $63 \%$ of women under 45 . Sample distribution in terms of levels of formal education showed a predominance of consumers with a high school degree. Motherhood was considered a differential determinant of the respondents' stage in their lifecycle; the indicator for this stage in the lifecycle was the presence of children under 18 . Of those interviewed, $57 \%$ were mothers.

Critical events that had occurred in the lives of the interviewees were highlighted in the qualitative study and included in the model. The value of this corresponds with the number of events that had occurred in the last six months. Most respondents reported not having undergone any critical situations during this period (63.4\%). However, when comparing both groups (non-default and default), a difference was observed in the percentage of consumers who had undergone at least one critical event. While $53 \%$ of members within the group of defaulters reported the occurrence of at least one critical event, this percentage dropped to $25 \%$ in the other group.

\section{Confirmatory factor analysis}

The correlation matrix and univariate normality of the data were evaluated, since these are important aspects for the CFA. In this study, the asymmetry reached a maximum of 2.85 and 7.88 kurtosis, which indicates acceptable deviations from normality. The mental budget and financial management constructs had four indicators each (scales adapted from Antonides, Groot, \& Raaij. (2011)), and displayed acceptable deviations from normality.

The measurement model for the latent constructs was assessed using a CFA. This analysis identifies the convergent validity of the measurement model, or whether the indicators are correlated when measuring the same construct (Aranha \& Zambaldi, 2008). The constructs related to the personal characteristics of the constructs were analyzed separately for the constructs that represent financial management. During the process, some indicators were discarded due to the results from the analysis of modification indexes.

As a result of the CFA for personal characteristics, some indicators were discarded. To construct the final model, self-control was measured using seven indicators. One indicator for the construct of preference for credit was eliminated, leaving a total of two indicators. The fit indexes were within the required parameters, and the measurement model was considered appropriate (model parameters: $\mathrm{x}^{2} / \mathrm{df}=1.20, \mathrm{p}$-value $=0.06$, RMSEA $=0.04, \mathrm{CFI}=0.96, \mathrm{TLI}=0.96, \mathrm{NFI}=0.81$ ). Table 1 shows the in dicators of the personal characteristics' latent variables, their measures, and the result of the CFA.

The divergent validity was also investigated via CFA, with the constructs combined two by two. The results point to the existence of three different constructs ( $p<0.01$ and $p<0.05$ ), as expected. The composite reliability indexes showed appropriate values for self-control (o.683), preference for credit (0.733) and propensity to plan (o.867).

The same procedure was performed for the two constructs related to financial management. As a result of the CFA for the management variables, one of the indicators for financial control was discarded, leaving three indicators. For the mental budget construct, all four indicators remained in the model. Table 2 shows the measures of the indicators for the household financial management constructs and the results of the CFA. The fit indexes were within the parameters, and the measurement model is thus considered appropriate (model parameters: $\mathrm{x}^{2} /$ $\mathrm{df}=1.81, \mathrm{p}$-value $=0.035, \mathrm{RMSEA}=0.07, \mathrm{CFI}=0.96, \mathrm{TLI}=0.94$, $\mathrm{NFI}=0.92$ ). The divergent validity of the research was also considered through CFA. The results point to the existence of two different constructs $(p<0.01)$. The composite reliability indexes 
showed appropriate values for the two constructs: mental budget (0.730) and control (0.696). Based on these results, the two constructs were considered in the analysis of the model.

\section{TABLE 1. Personal characteristics: indicators and CFA results}

\begin{tabular}{|c|c|c|c|c|c|c|c|c|c|}
\hline Indicators & & $\mathbf{N}$ & Min. & Max. & Mean & SD & Asymmetry & Kurtosis & CFA \\
\hline $\mathrm{ACa}$ & I am good at resisting temptation. & 165 & 1 & 5 & 3.12 & 1.58 & 0.02 & -1.63 & \\
\hline ACb (Inv.) & I have a hard time breaking bad habits. & 165 & 1 & 5 & 3.99 & 1.41 & -1.19 & -0.06 & * \\
\hline ACc (Inv.) & I am lazy. & 165 & 1 & 5 & 4.65 & 0.85 & -2.85 & 7.88 & \\
\hline ACd (Inv.) & I say inappropriate things. & 165 & 1 & 5 & 3.79 & 1.25 & -0.98 & -0.10 & \\
\hline ACe (Inv.) & I do certain things that are bad for me, if they are fun. & 165 & 1 & 5 & $4 \cdot 41$ & 1.06 & -2.00 & 3.23 & * \\
\hline ACf & I refuse things that are bad for me. & 165 & 1 & 5 & 3.81 & 1.55 & -0.78 & -1.13 & \\
\hline ACg (Inv.) & I wish I had more self-discipline. & 165 & 1 & 5 & 3.38 & 1.57 & -0.46 & -1.39 & * \\
\hline ACh (Inv.) & Pleasure and fun sometimes keep me from getting work done. & 165 & 1 & 5 & $4 \cdot 52$ & 1.10 & -2.45 & $4 \cdot 92$ & * \\
\hline ACi (Inv.) & I have trouble concentrating. & 165 & 1 & 5 & $4 \cdot 38$ & 0.99 & -1.58 & 1.43 & * \\
\hline $\mathrm{ACj}$ & I am able to work effectively toward long-term goals. & 165 & 1 & 5 & $4 \cdot 12$ & 1.28 & -1.25 & 0.18 & \\
\hline $\mathrm{ACk}$ & $\begin{array}{l}\text { Sometimes I can't stop myself from doing something, } \\
\text { even if I know it is wrong. }\end{array}$ & 165 & 1 & 5 & $4 \cdot 30$ & 1.11 & -1.69 & 1.94 & * \\
\hline $\mathrm{ACl}$ & I often act without thinking through all the alternatives. & 165 & 1 & 5 & 4.28 & 1.16 & -1.60 & 1.48 & * \\
\hline $\mathrm{CPa}$ & I only focus on the short term. & 165 & 1 & 5 & 1.85 & 1.31 & 1.39 & 0.57 & * \\
\hline $\mathrm{CPb}$ & The future will take care of itself. & 165 & 1 & 5 & 1.98 & 1.60 & 1.19 & -0.42 & \\
\hline $\mathrm{CPC}$ & I live more for the day of today than for the day of tomorrow. & 165 & 1 & 5 & 2.25 & 1.52 & 0.86 & -0.86 & * \\
\hline $\mathrm{CPd}$ & $\begin{array}{l}\text { My convenience plays an important role in the } \\
\text { decisions I make. }\end{array}$ & 165 & 1 & 5 & 3.72 & 1.46 & -0.70 & -1.08 & \\
\hline PCa (Inv.) & It is best to first save money and then spend. & 165 & 1 & 5 & 2.64 & 1.50 & 0.45 & -1.27 & \\
\hline $\mathrm{PCb}$ & $\begin{array}{l}\text { I prefer to pay the purchases on installments then } \\
\text { expect to have money to pay cash. }\end{array}$ & 165 & 1 & 5 & 2.91 & 1.63 & 0.05 & -1.66 & * \\
\hline PCC & $\begin{array}{l}\text { I prefer to pay in installments even if the total cost is } \\
\text { more expensive. }\end{array}$ & 165 & 1 & 5 & 2.29 & 1.51 & 0.78 & -0.95 & * \\
\hline $\mathrm{PPa}$ & $\begin{array}{l}\text { I set financial goals for next 1-2 months for what I want } \\
\text { to achieve with my money. }\end{array}$ & 165 & 1 & 5 & 3.79 & 1.37 & -0.92 & -0.48 & * \\
\hline $\mathrm{PPb}$ & $\begin{array}{l}\text { I decide beforehand how my money will be used in the } \\
\text { next 1-2 months. }\end{array}$ & 165 & 1 & 5 & 3.88 & 1.31 & -1.07 & -0.05 & $\star$ \\
\hline PPc & $\begin{array}{l}\text { I actively consider the steps I need to take to stick to } \\
\text { my budget in the next } 1-2 \text { months. }\end{array}$ & 165 & 1 & 5 & 4.04 & 1.20 & -1.24 & 0.53 & * \\
\hline PPd & $\begin{array}{l}\text { I consult my budget to see how much money I have left } \\
\text { for the next 1-2 months. }\end{array}$ & 165 & 1 & 5 & 3.79 & 1.38 & -0.99 & -0.39 & * \\
\hline $\mathrm{PPe}$ & $\begin{array}{l}\text { I like to look to my budget for the next 1-2 months in } \\
\text { order to get a better view of my spending in the future. }\end{array}$ & 165 & 1 & 5 & 4.07 & 1.30 & -1.33 & 0.51 & * \\
\hline PPf & $\begin{array}{l}\text { It makes me feel better to have my finances planned } \\
\text { out in the next 1-2 months. }\end{array}$ & 165 & 1 & 5 & $4 \cdot 47$ & 0.97 & -2.10 & 3.85 & * \\
\hline
\end{tabular}

Note: Indicators used in final analysis. 
TABLE 2. Financial Management: Indicators and CFA results

\begin{tabular}{|c|c|c|c|c|c|c|c|c|c|}
\hline Indicators & & $\mathbf{N}$ & Min. & Max. & Mean & SD & Asymmetry & Kurtosis & CFA \\
\hline $\mathrm{OMc}$ & $\begin{array}{l}\text { If I spend more on one thing, I economize on other } \\
\text { expenses. }\end{array}$ & 165 & 1 & 5 & 4.13 & 1.22 & -1.43 & 0.93 & * \\
\hline OMd & $\begin{array}{l}\text { If I spend more than normal on one thing in one month, I } \\
\text { spend less on other things in the next month. }\end{array}$ & 165 & 1 & 5 & 4.24 & 1.10 & -1.58 & 1.72 & * \\
\hline GRa & I manage my daily financial affairs in a very organized way. & 165 & 1 & 5 & 3.91 & 1.24 & -0.92 & -0.36 & * \\
\hline GRb (Inv) & $\begin{array}{l}\text { I am very impulsive and I am tempted to buy things even } \\
\text { when in fact I do not have the money for it. }\end{array}$ & 165 & 1 & 5 & 3.86 & 1.41 & -0.99 & -0.45 & \\
\hline
\end{tabular}

Note: Indicators used in final analysis.

\section{Testing relationships in the proposed model}

The conceptual model used in the study could lend itself to structural equation modeling. However, as the dependent variables (default and savings) are binary in nature, a series of regressions was conducted to assess the relationship between the variables. Achieving the regressions via parsimony was considered adequate.

\section{Mental budget and antecedents}

The results of the regression analysis for mental budget indicate that only the variable propensity to plan (Beta $=0.691, \mathrm{t}=$ 11.163, $p=0.000$ ) showed significant results. Individuals with a greater tendency to plan usually have a mental budget. A mental budget entails a process of planning, since consumers need to set spending limits for the various categories.

\section{Financial control and antecedents}

For financial control, the results point to three variables that influence this process: self-control (Beta $=0.224, t=3.651, p=$ 0.000 ), preference for credit (beta pad. $=0.170, t=2.911, p=$ 0.004 ), and propensity to plan (Beta $=0.611, t=10.028, p=$ $0.000)$. Thus, individuals with more self-control and more tendencies to plan are better able to manage their finances. Contrary to initial expectations, preference for the use of credit had a positive relationship with financial management. One can speculate that in this case, although the use of credit can bring more complexity to the process of managing finances, individuals who prefer to use credit to pay for their purchases need to manage their finances more accurately.

\section{Default and household financial management}

The relationship between the variables of financial management (mental budget and financial control) and default was tested a binary logistic regression analysis where the dependent variable was represented by the presence of the individual in the group of defaulters. The relationship between financial control and the occurrence of default was negative and significant $(B=-0.224, p=$ 0.021 ). Thus, as they can manage their finances better, these individuals reduce the risk of becoming defaulters. The model has a correct classification percentage of $60 \%$. By comparing the classification matrix with and without the model, a $22 \%$ increase in the accuracy of classification of defaulters can be noted.

\section{Savings and household financial management}

The relationships between the variables of financial management and savings were also tested by means of a binary logistic regression analysis. The results showed a positive relationship between financial control and savings $(B=0.531, p=0.025)$. Good management seems to favor savings, especially residual savings, as presented by Katona (1974) and reported by Lindqvist (1981), resulting from cash management. The regression model shows $66.1 \%$ accuracy in terms of classification of individuals as savers and non-savers. 


\section{Default and antecedents}

When testing the direct relationship between personal characteristics and sociodemographic variables and default, the only variable that showed a significant result was the occurrence of critical events $(B=0.909, p=0.001)$. The model parameters indicate $66.7 \%$ correct classification for both groups. The results point to a direct relationship between the occurrence of critical events and default $-18.8 \%$ of respondents reported having lost a job within the last six months. This result is consistent with studies in which defaulters reported unemployment as the main reason for failure to pay (Boa Vista, 2012).

Thus, default seems to be influenced by two main factors: financial control and the occurrence of critical events. The test of a partial model to evaluate these relationships indicates significant relationships between the variables of financial control $(B=-0.373, p=0.035)$ and critical events $(B=0.911, p=0.00)$ and default.

\section{Savings and antecedents}

The test of the relationship between personal characteristics and sociodemographic variables and savings highlighted two variables of significant and direct relationships with savings: propensity to plan $(B=0.424, p=0.047)$ and educational level $(B=0.143$, $p$-val$\mathrm{ue}=0.047)$. The positive relationship between propensity to plan and savings can be easily explained, since saving requires planning in most cases. The positive relationship between educational level and savings suggests that more educated individuals have a better understanding of compound interest, and a better view of the negative compounding effect over time, which leads these consumers to save more. An alternative model can be suggested, in which the financial control variable would play a mediator role in the relationship between propensity to plan and savings.

\section{Mediating role of household financial management constructs}

Mediators explain how and why these effects occur (Baron \& Kenny, 1986). Inserting a mediating variable into the model of the relationship between two variables neutralizes or reduces the impact of the independent variable on the dependent variable (Vieira, 2009). The results of the coefficients and errors are used to conduct the Sobel test (Baron \& Kenny, 1986). In this study, we used a calculator for the Sobel test, which is available at http://quantpsy.org/sobel/sobel.htm. Only the financial control construct emerged as a mediator between the antecedents and the consequences (default and savings).
For savings, the results of the mediator role of financial control showed significant results only for the relationship between propensity to plan and savings. The results are: regression $a-B=0.626, p$-value $=0.000$; regression $b-B=0.584$, $p$-value $=0.005$, regression $c-B=0.500, p$-value $=0.012$; regression c' NS. The test has a significant value (test statistic 2.717 , $p$-value $=0.007$ ), demonstrating the role of financial control as a mediator between propensity to plan and savings. In this case, the greater the propensity to plan, the better the financial control and increased savings capacity.

Tests were also performed to understand whether financial control acts as a mediator between the personal characteristics (self-control, preference for credit and propensity to plan) and default. Tests were performed for each of the relations. In all three cases, the financial control variable appears to act as a mediator between personal characteristics and default (test statistic $=-1.956$ for self, $p$-value $=0.05$, test statistic for preference for credit $=-1.816$, $p$-value $=0.069$; statistical test for propensity to plan $=-2.269, p$-value $=0.023)$. We can say that the relationship between consumer characteristics and the occurrence of default can be better explained with reference to financial control, suggesting that the model proposed in the study reflects the relationships between the variables investigated. This result has important implications in the fight against default, since it reinforces the finding that stimulation for consumers to improve their financial control can reduce default.

\section{Framework after model calibration}

The results of this exploratory research are very promising. Although not all relationships in the proposed model were confirmed, the basic framework of the model seems to properly portray the household financial management phenomenon. We confirmed the influence of the three antecedent categories (personal characteristics, sociodemographic data and critical events) on how consumers manage their household finances; these in turn influence the outcomes in terms of default or savings. Figure 2 shows the resulting model following the statistical procedures, and suggests how the variables are related (i.e., positively or negatively).

\section{GENERAL DISCUSSION}

This research used two complementary empirical studies to investigate the antecedents and consequences of managing household finances of lower-middle-class families. The results demonstrate the diversity of consumer behavior in relation to 
managing household finances, and suggest that consumers who put less effort into managing finances tend to incur more default situations.

The main contribution of this study is the integration of several fragments within a theoretical model that identifies the antecedents and consequences of managing household finances. To construct the model, we investigated personal characteristics and behaviors; these variables are usually researched in the areas of marketing, psychology and economics, and more recently in the area of financial decision-making, which often incorporates knowledge from these other three areas. The model initially proposed in this study was de- rived from elements that emerged from both the qualitative research and the literature review regarding consumer behavior. These constructs have never been investigated in such an integrated fashion before; nor have propositions been developed about the relationship between them. The model tested in the quantitative study offers a valuable conceptual framework of the antecedents and consequences of the financial management process, thereby enabling a more thorough understanding of the process. The resulting model, presented in Figure 2 , suggests specific assumptions about the relationship between antecedents and consequences of the household financial management model.

Figure 2. Framework after model calibration

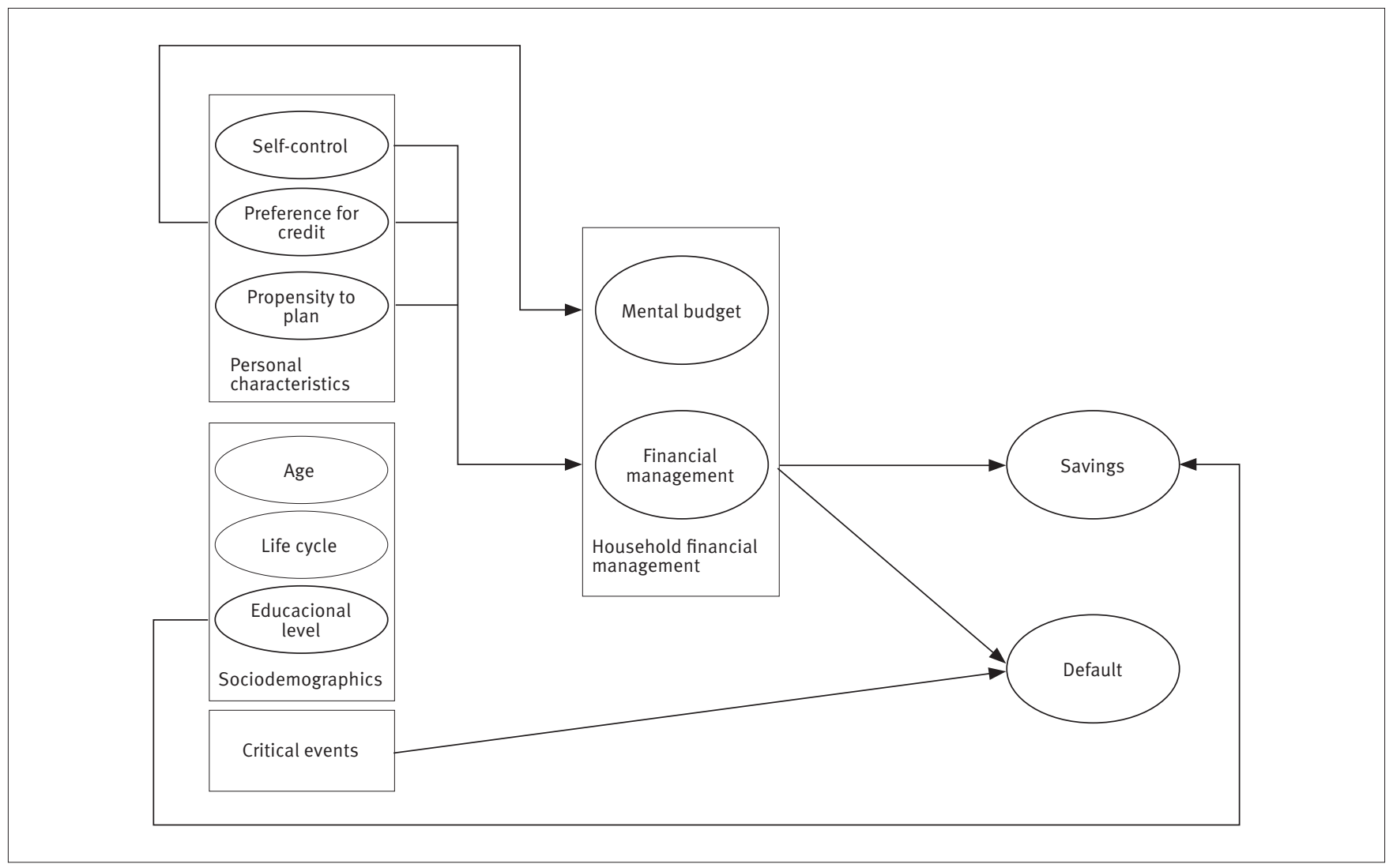

Another contribution of the study refers to investigation of the phenomenon of managing household finances using a population with severe income restrictions and lower levels of education (or education of lower quality), which entails a different context from the upper-income and better-educated consumers used in most studies conducted in the USA, which correspond to the major part of the literature in the area. Although our investigation did not aim to develop a comparative study to identify differences between the responses of upper- and low- er-income consumers, some of our findings have not been explored or demonstrated in the existing literature. The findings might suggest possible peculiarities about financial management behavior among Brazilian lower-middle-class households, such as: inadequate focus on control, the use of credit card limits as a device for financial control, non-existing or weak focus on short- or long-range planning, a widespread aspect.

From a managerial perspective, this study contributes to the knowledge in the area, as it shows aspects of the finan- 
cial behavior of lower-income consumers that may be relevant to companies that serve this audience. Factors like self-control and propensity to plan could be incorporated into future models to improve the companies' default predictions. Individuals with lower levels of self-control tend to manage their finances inadequately, just as those with a lower tendency to plan, leading to higher incidences of bad debt situations.

In order to help consumers with their management of revenue and expenditure, the financial system could create appropriate products, including information to promote consumers' control of household budgets; the development of a simplified bill that facilitates consumers' understanding; the inclusion of historical spending information on the credit card bill, as indicated in water and electricity bills (a historical account perspective could help consumers realize their spending trends and promote the necessary changes for better financial management); and highlighting purchases in installments on the credit card bill, with a projection of the installments to be paid in the coming months, with an indication of the balance still available for purchases on credit. For financial institutions, this aid to household budgetary control has the potential to increase consumer confidence and generate more loyal customers. In addition, it can help promote consumers' awareness and facilitate their financial education in a more effective way.

The survey results show the need to educate consumers to better manage their income and expenses and plan their budgets; or, in other words, to promote consumers' "financial literacy". A lack of knowledge and skill in dealing with budget issues, interest, investments, loans and other banking services eventually lead consumers to incur in errors that may have serious consequences for their financial situations. In this sense, public policies should be developed to educate consumers and encourage household financial planning, in a way that improves consumers' saving habits. Educational campaigns on the benefits of reserving resources for future needs - for emergency situations, as highlighted by the interviewees, for the purchase of goods of greater value or for retirement - could help families increase their surplus, thereby minimizing the actual trend of difficult financial situations.

The adoption of dichotomous measurements for the dependent variables, default and savings, restricted the use of more sophisticated statistical tools such as structural equation modeling. The development of other continuous indicators for these two variables could eliminate this limitation. Another limitation of the study is that the sample was restricted to a single segment: lower-middle-class consumers. Future studies could investigate other economic segments to offer more generalizable results and provide a comparison among findings. The results found in São Paulo should not be generalized to other re- gions of the country. It is possible that consumers of the same income but living in other regions of the country might systematically present different behavioral characteristics, due to cultural or social structure diversity among regions.

\section{REFERENCES}

Abecs. (2013). Pesquisa Mercado de Meios Eletrônicos de Pagamento, Ano VI. Retrieved on 1st November 2013 from http://www.abecs.org.br/ site2012/admin/arquivos/pesquisas/\%7B6228FAC8-DD15-4DEB-A3DC965B8BF55047\%7D_APRESENTAÇÃO_CONGRESSO_FINAL_29_10.pdf.

Amar, M., Ariely, D., Ayal, S., Cryder, C., \& Rick, S. (2011). Winning the battle but losing the war: the psychology of debt management. Journal of Marketing Research, 48(Special), 38-50.

Anderson, F., Chomsisengphet, S., Glennon, D., \& Li, F. (2011). The changing pecking order of consumer defaults. Retrieved on 5 October 2012 from http://ssrn.com/abstract $=1939507$.

Antonides, G., Groot, I. M., \& Raaij, W. F. (2011). Mental budgeting and the management of household finance. Journal of Economic Psychology, $32(4), 546-555$.

Aranha, F. \& Zambaldi, F. (2008). Análise fatorial em administração. São Paulo: Cengage Learning.

Banco Central. (2013). Política monetária e operações de crédito do SFN - Nota para a Imprensa. Retrieved on 25 January 2013 from http://www. bcb.gov.br/?ECOIMPOM.

Baron, R. \& Kenny, D. (1986). The moderator-mediator variable distinction in social psychological research: conceptual, strategic, and statistical considerations. Journal of Personality and Social Psychology, 51(6), $1173-1182$.

Baumeister, R. (2002). Yielding to temptation: self-control failure, impulsive purchasing, and consumer behavior. Journal of Consumer Research, 28(4), 670-676.

Boa Vista. (2012). Pesquisa perfil do inadimplente: $3^{0}$ semestre de 2012 , Indicadores e Estudos Econômicos. Retrieved on 25 January 2013 from http://www.boavistaservicos.com.br/wp-content/uploads/2012/11/ pesquisaperfil.pdf.

Cappellozza, A. \& Sanchez, O. (2011). Análise de decisões sobre uso de tecnologia: um estudo no setor de telefonia móvel fundamentado nos axiomas da economia comportamental. RAC-Revista de Administração Contemporânea, 15(6), 1078-1099.

Da Silva, R., Lagioia, U., Maciel, C., \& Rodrigues, R. (2009). Finanças Comportamentais: um estudo comparativo utilizando a teoria dos prospectos com os alunos de graduação do curso de ciências contábeis. Revista Brasileira de Gestão de Negócios, 11(33), 383-403.

Du, R., Kamakura, \& Wagner A. (2008). Where did all that money go? Understanding how consumers allocate their consumption budget. Journal of Marketing, 72(6), 109-131.

Ferreira, V. (2007). Psicologia econômica, RAE-Revista de Administração de Empresas, 47(3), 122-125.

Fonseca, P, \& Muramatsu, R. (2008). Economia comportamental e trajetórias de consumo intertemporal - anomalias e evidências do caso brasileiro, Revista Jovens Pesquisadores, n.9. 
Halfeld, M. \& Torres, F. (2001). Finanças comportamentais: aplicações no contexto brasileiro. RAE-Revista de Administração de Empresas, 41(2), 64-71.

Heath, C. \& Soll, J. (1996). Mental budgeting and consumer decisions. Journal of Consumer Research, 23(1), 40-52.

Johnson, D., Rogers, J., \& Tan, L. (2001). A century of family budgets in the United States. Monthly Labor Review, 28, 28-45.

Katona, G. (1974). Psychology and consumer economics, Journal of Consumer Research, 1(1), 1-8.

Kimura, H., Basso, L., \& Krauter, E. (2006). Paradoxos em finanças: teoria moderna versus finanças comportamentais. RAE-Revista de Administração de Empresas, 46(1), 41-58.

Kirchler, E., Hoelzl, E., \& Kamleitner, B. (2008). Spending and credit use in the private household. The Journal of Socio-Economics, 37(2), 519-532.

Lindqvist, A. (1981). A note on determinants of household saving behavior. Journal of Economic Psychology, 1(1), 39-57.

Lynch, J. (2011). Introduction to the Journal of Marketing Research special interdisciplinary issue on consumer financial decision making. Journal of Marketing Research, 48(SPL), 4-8.

Lynch, J., Netemeyer, R., Spiller, S., \& Zammit, A. (2010). A generalizable scale of propensity to plan: the long and the short of planning for time and for money. Journal of Consumer Research, 37(1), 108-128.

Mattoso, C. (2005). Identidade, inserção social e acesso a serviços financeiros: um estudo na favela da Rocinha. $237 \mathrm{f}$. Doctoral thesis in Business - Universidade Federal do Rio de Janeiro, Instituto COPPEAD de Administração, Rio de Janeiro.

Mayer, C., Pence, K., \& Sherlund, S. (2008). The rise in mortgage defaults, Finance and Economics Discussion Series Divisions of Research \& Statistics and Monetary Affairs, Washington, D.C.: Federal Reserve Board.

Neri, M. (2011). A nova classe média: o lado brilhante da base da pirâmide. São Paulo: Saraiva.

Oliveira, de E., Silva, S. Silva, W. (2005). Finanças Comportamentais: um estudo sobre o perfil comportamental do investidor e do propenso investidor. Il Seminário de Gestão de Negócios da FAE Business School, pp. 1-15.

Ponchio, M. (2006). The influence of materialism on consumption indebtedness in the context of low income consumers from the city of Sao Paulo. 175 f. Doctoral dissertation in Business, Escola de Administração de Empresas de São Paulo, Fundação Getulio Vargas, São Paulo.

Prelec, D. \& Loewenstein, G. (1998). The red and the black: mental accounting of savings and debt. Marketing Science, 17(1), 4-28.

Raghubir, P. \& Srivastava, J. (2008). Monopoly money: the effect of payment coupling and form on spending behavior. Journal of Experimental Psychology: Applied, 14(3), 213-225.

Silva, H. (2004). Análise do orçamento de uma amostra de famílias brasileiras: um estudo baseado na Pesquisa de Orçamentos Familiares do IBGE. Master dissertation Biblioteca Digital de Teses e Dissertações. Universidade de São Paulo.
Silva, H., Parente, J., \& Kato, H. (2009). Segmentação da baixa renda baseado no orçamento familiar. Revista de Administração Faces, 8(4), 98-114.

Soll, J., Keeney, R., \& Larrick, R. (2011). Consumer misunderstanding of credit card use, payments, and debt: causes and solutions, paper presented at the 2011 Boulder Summer Conference on Consumer Financial Decision Making, Boulder (June 26-28).

Soman, D. (1998). The illusion of delayed incentives: evaluating future effort-money transactions. Journal of Marketing Research, 35(4), 427437.

Soman, D. \& Cheema, A. (2002). The effect of credit on spending decisions: the hole of the credit limit and credibility. Marketing Science, 21(1), 32-53.

Soman, D. \& Cheema, A. (2011). Earmarking and partitioning: increasing saving by low-income households. Journal of Marketing Research, 48(SPL), 14-22.

Soman, D. \& Lam, V. (2002). The effects of prior spending on future spending decisions: the hole of acquisition liabilities and payments. Marketing Letters, 13(4), 359-372.

Spiller, S. (2011). Opportunity cost consideration. Journal of Consumer Research, 38(4), 595-612.

Tangney, J., Baumeister, R., \& Boone, A. (2004). High self-control predicts good adjustment, less pathology, better grades, and interpersonal success. Journal of Personality, 72(2), 271-324.

Thaler, R. (1985). Mental accounting and consumer choice. Marketing Science, 4(3),199-214.

Thaler, R. (1993). Mental Accounting: parenthetical remarks. Washington, DC: Meeting of the Society for Judgment and Decision Making.

Thaler, R. \& Benartzi, S. (2004). Save more tomorrow: using behavioral economics to increase employee saving. Journal of Political Economy, $112(1), 164-187$.

Thaler, R. \& Sustein, C. (2009). Nudge: o empurrão para a escolha certa. Rio de Janeiro: Elsevier.

Vieira, V. (2009). Moderação, mediação, moderadora-mediadora e efeitos indiretos em modelagem de equações estruturais: uma aplicação no modelo de desconfirmação de expectativas. RAUSP-Revista de Administração da Universidade de São Paulo, 44(1), 17-33.

Wärneryd, K. (1989). On the psychology of saving: an essay on economic behavior. Journal of Economic Psychology, 10(4), 515-541.

Webley, P. (1995). Accounts of accounts: en route to an economic psychology of personal finance. Journal of Economic Psychology, 16(3), 469-475.

Webley, P. \& Nyhus, E. (1998). Dynamic approach to consumer debt. Working paper, Dec. 